\title{
City-Based Risk Assessment of Sea Level Rise Using Topographic and Census Data for the Turkish Coastal Zone
}

\author{
Tuncay Kuleli
}

Received: 28 March 2008 /Revised: 22 November 2009/Accepted: 24 November 2009 / Published online: 27 January 2010

(C) The Author(s) 2010. This article is published with open access at Springerlink.com

\begin{abstract}
Turkish coastal zone elevation to sea level rise was illustrated using a digital elevation model and methods in a geographical information system. It was intended to determine several parameters such as population, settlements, land use, wetlands, contribution to national agricultural production, and taxes at risk using high-resolution Shuttle Radar Topography Mission topographic, orthorectified Landsat Thematic Mapper Mosaics and census data with geographical information system methods within 0 - to 10-m elevation of the national level. All parameters were examined for coastal cities, coastal districts, settlements, and villages' status. It was found that approximately $7,319 \mathrm{~km}^{2}$ of land area lies below the $10-\mathrm{m}$ contour line in Turkey and is, hence, highly vulnerable to sea level rise. Twenty-eight coastal cities, 191 districts, and 181 villages or towns are located below the $10-\mathrm{m}$ contour line in the study area. The findings suggest that the Turkish Ministry of Environment should declare new areas protected and develop special environmental programs at the national level.
\end{abstract}

Keywords Coastal zone · Elevation · Sea level rise · SRTM . Turkey

\section{Introduction}

The International Panel on Climate Change reports that climate change will have many negative effects, including increased intensity of storms, floods, drought, rising sea

\section{T. Kuleli $(\bowtie)$}

The University of Cukurova Faculty of Fisheries, Balcali 01330 Adana, Turkey

e-mail: kuleli@cu.edu.tr levels, and loss of biodiversity. Sea level rise (SLR) threatens countries with high population densities and economic activity in coastal areas. The 2001 IPCC Third Assessment Report (Church et al. 2001) projected a globalaveraged SLR of 20-70 cm between 1990 and 2100 using the full range of IPCC greenhouse gas scenarios and a range of climate models. When an additional uncertainty for land-ice changes was included, the range of projected SLR was 9-88 cm.

Concern that SLR projections are biased low has been reinforced by a comparison of observed and projected SLR from 1990 to the present. For this period, sea level has been rising more rapidly than the central range of the IPCC (2001, 2007) model projections (Church et al. 2008). Until now, SLR has also been approximately two to four times faster than predicted in the 2007 IPCC reports (IPCC 2007; Meehl et al. 2007). In Europe, regional effects may result in SLR up to $50 \%$ higher than global estimates (Woodworth et al. 2005). The impact of the North Atlantic Oscillation on winter sea levels provides an additional uncertainty of $0.1-$ $0.2 \mathrm{~m}$ to the estimates (Hulme et al. 2002; Tsimplis et al. 2004).

The impact of SLR has been demonstrated in beach erosion and loss of wetlands. Other effects, including increased seawater temperatures, changes in precipitation patterns and storm tracks, and frequency and intensity also influence coastal systems both directly and through interactions with SLR. The impact of SLR also has implications for the world socioeconomic structure. It is estimated that 1.2 billion people, approximately $23 \%$ of the world's population, live within $100 \mathrm{~m}$ above sea level and $100 \mathrm{~km}$ from a coast (Nicholls and Small 2002; Nicholls 2003), and population densities in coastal regions are approximately three times the global average, with maximum densities occurring below $20 \mathrm{~m}$ in elevation (Nicholls 
2003). Low-lying populated areas are the most vulnerable to SLR.

Several studies have estimated the potential impact of SLR for some developed countries (Baarse et al. 1994; Bijlsma et al. 1996; $\mathrm{Ng}$ and Mendelshon 2005; Zeidler 1997), developing countries (Adam 1995; Dennis et al. 1995; French et al. 1995; Han et al. 1995; Warrick et al. 1996), and specific world regions (Yim 1995). Only a few studies, such as Nicholls and Mimura (1998) and Nicholls and Tol (2006), have estimated the impact of SLR on a wide regional or world scale. Those studies evaluated the impact of extreme climate scenarios, such as a 5-m SLR. However, while indicators of impact include primarily land loss, affected population, and loss of capital and wetlands, other studies have evaluated different indicators or regions, making it difficult to compare the relative magnitude of impact across countries and/or regions.

Although a national evaluation of SLR has not been conducted in Turkey, local research has been conducted which assessed the risk of coastal flooding and coastal vulnerability to inundation in Turkey due to SLR until 2205 (Demirkesen et al. 2007a, b). In the present study, an index was developed to determine risk of SLR to Turkish coastal cities using eight parameters. The parameters, which included population, settlements, land use, wetlands, contribution of national agricultural production, and taxes, were determined using geographical information system (GIS) methods with high-resolution Shuttle Radar Topography Mission (SRTM) topographic, orthorectified Landsat Thematic Mapper Mosaics and censuses within 0- to 10-m elevation of the national level. All parameters were examined at the level of coastal city, coastal district, settlement, and village status.

\section{The Coastal Environment of Turkey}

The Turkish coastal environment was researched from several different perspectives. The most recent research document, Coastal Area Management in Turkey, was prepared by the Priority Actions Program, Regional Activity Centre of the Mediterranean Action Plan. The author of the document is Professor Erdal Ozhan, the Chairman of Mediterranean Coastal Environment Organization (MEDCOAST; PAP/RAC 2005). According to the research document, the Turkish coastal environment was briefly described as follows:

The total length of the Turkish coastline is $8,333 \mathrm{~km}$, $1,067 \mathrm{~km}$ of which are island shores. Different regions of the coast are bordered by one of four seas: the Black Sea $(1,701 \mathrm{~km}, 20.4 \%)$, the Sea of Marmara $(1,441 \mathrm{~km}, 17.3 \%)$, the Aegean Sea $(3,484 \mathrm{~km}, 41.8 \%)$, and the Mediterranean Sea $(1,707 \mathrm{~km}, 20.5 \%$; Gunay 1987). These four coastal regions have distinct geographical features. Mountain ranges run parallel to the Black Sea coast, especially in eastern Turkey, limiting the size of the coastal area to a minimum and having a marked influence on the region's climate.

The western Mediterranean coast has geological features similar that of the eastern Black Sea coast (e.g., high mountain ranges running in close proximity to the coastline). However, the climatology of the western Mediterranean coast is very different. The width of the coastal area along the eastern Black Sea and the western Mediterranean Sea is very narrow (on the order of a few hundred meters), rendering the areas unsuitable for many coastal uses, including urbanization.

Mountains run perpendicular to the Aegean coastal area, allowing rivers, such as the Buyuk Menderes, to form fertile alluvial plains and productive deltas. Due to the perpendicular orientation of the mountains, the Turkish Aegean coastline is highly indented and houses numerous bays and coves that have been inhabited by humans since historic times. Thus, the Aegean coast is extremely important in terms of cultural sites and resources, and it is a prime area for tourism, recreation, and other coastal uses that are supported by its numerous coastal features and natural attractions. Other alluvial plains are situated along the western Black Sea coast (e.g., Kizilirmak, and Yesilirmak) and the middle-toeastern Mediterranean coast (e.g., Goksu, Seyhan, Ceyhan and Asi). The coastal areas along these alluvial and deltaic shores widen significantly from several kilometers to tens of kilometers, providing highly productive agricultural land.

The coastal area along the Sea of Marmara is suitable for human development. The terrain is not as rugged as the eastern Black Sea and the western Mediterranean coasts. The proximity of the Marmara coast to the city of Istanbul and Europe contributes to the potential development value of the Marmara coast, which is relatively more developed and densely populated.

Turkey is divided into seven geographic regions, four of which are named for the seas that they border. The Black Sea (Karadeniz) Region is often referred to in terms of the eastern and the western parts. These geographic regions are very large areas. The seven geographic regions are further divided into provinces that are essentially political (administrative) units. The four geographic regions of Turkey that have a coastline along one of the four seas for which they are named (and the provinces they include) are the Black Sea Region (Artvin, Rize, Trabzon, Giresun, Ordu, Samsun, Sinop, Kastamonu, Bartın, Zonguldak, Duzce, and Sakarya), The Marmara Region (Istanbul, Kirklareli, Tekirdag, Edirne, Canakkale, Balikesir, Bursa, Yalova, and Kocaeli), the Aegean Region (Izmir, Aydin, and Mugla), and the Mediterranean Region(Antalya, Icel, Adana, and 
Hatay). The boundaries of the provinces have been drawn based on administrative features. Each of the coastal provinces occupies both coastal and inland areas. Provinces are further divided into districts ("ilce" in Turkish; Fig. 1).

Turkey is one of the richest countries in terms of wetlands in Europe. The Turkish wetlands, including artificial lakes, cover an area of 1,851,000 ha. Fifty-eight of the total 250 wetlands of Turkey are considered "internationally important," and 18 of these are acknowledged as "class A" wetlands. Seventy-six wetlands, with a total area of 1,240,000 ha, are important bird sanctuaries (Ministry of Environment 2002). Of nine wetlands (total area $159,300 \mathrm{ha}$ ) that are included in the Ramsar List, four are located in coastal zones (Goksu Delta, Gediz Delta, Akyatan Lagoon, and Kizilirmak Delta; Ministry of Environment 2001).

Turkey has 72 lagoons of various sizes distributed along its coastline. The Aegean coast has the greatest number of lagoons (total lagoon area $\sim 20,000 \mathrm{ha}$ ) and fish production ( $\sim 562$ tons/year). Two lagoons, Bafa and Koycegiz, account for $60 \%$ of the total lagoon area along the Aegean coast. The lagoons along Turkey's Black Sea and Mediterranean coasts are primarily part of the deltaic systems. Lagoons of the Kizilirmak delta on the western Black Sea coast and those of the Goksu, Seyhan, and Ceyhan deltas on the eastern Mediterranean coast are important pristine preservation areas (Deniz 2002).
Approximately $845 \mathrm{~km}$ of the Turkish coastline comprise sand dunes. Until recently, coastal dunes sustained significant damage due to road construction, plantations, sand extraction, secondary houses, and tourism projects (SPO 2001).

Agriculture in the Turkish coastal regions is most important across the alluvial deposits of the major rivers, such as the Yesilirmak and Kizilirmak (Black Sea region); the Gediz, Buyuk Menderes, and Dalaman (Aegean region); and the Goksu, Seyhan, and Ceyhan (Mediterranean region). The agricultural products are usually varieties with high market value, including cotton, tobacco, tea, citrus and other fruits, olives, and grapes. In 1989, the agricultural sector was consistently losing to tourism development and services, invariably in the tourism centers along the Aegean and the Mediterranean, and industry and urbanization around the Sea of Marmara.

\section{Sea Level Monitoring/Measurement}

Yildiz et al. (2003) report on ongoing sea level monitoring and measurement activities in Turkey. The Turkish National Sea-Level Monitoring System (TUSELS) includes a Data Center based in Ankara and tide gauge stations in the following locations: Antalya-II and Erdemli at the Mediterranean coast, Bodrum-II and Mentes at Aegean Sea

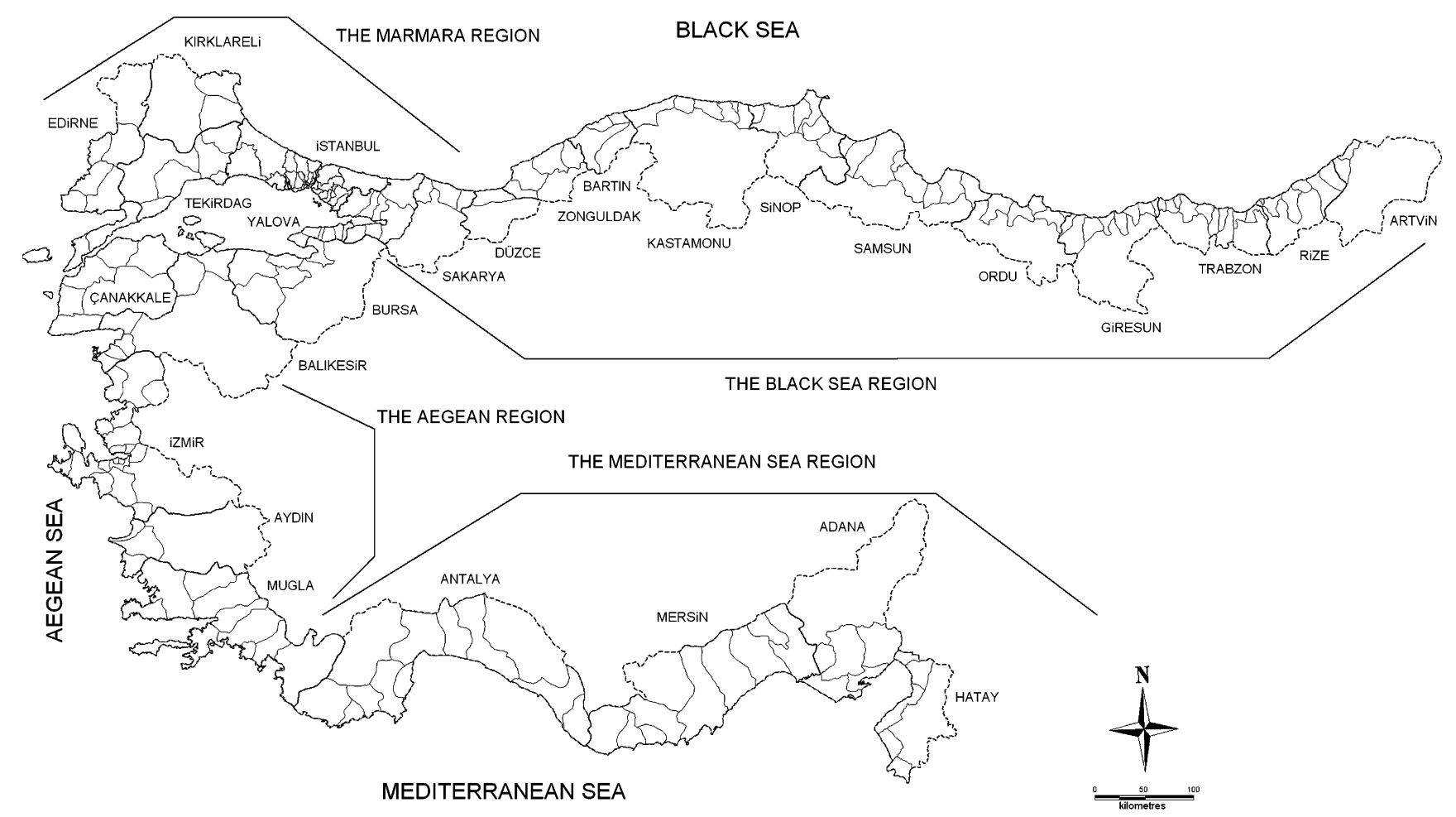

Fig. 1 Turkish coastal regions, cities, and districts map 
coast, Erdek at Sea of Marmara coast, and Amasra, Trabzon-II, and Igneada at the Black Sea coast. Within the TUSELS framework, sea level measurements and ancillary meteorological parameters are collected digitally with high accuracy. The calculation of the hourly sea level values for the other years is based on the tidal constituents obtained taking into consideration the tidal prediction. Hourly sea level values of 18 years (1985-2002) for Antalya-II, Bodrum-II, and Mentes tide gauges and of 19 years (1984-2002) for Erdek tide gauge are qualitycontrolled by comparing them with the predicted values by removing datum shifts and time errors as much as possible. A 119-point low-pass filter is applied to the hourly sea level values in the computation of daily values, and the daily values are used to obtain monthly values with a simple average. Harmonic analysis is applied to the monthly sea level values of four tide gauges, and mean sea levels (MSL) and relative changes of MSLs are calculated. This procedure yields relative MSL changes at Antalya-II, Bodrum-II, Mentes, and Erdek as $8.7 \pm 0.8,3.3 \pm 1.11,6.8 \pm 0.9$, and $9.6 \pm 0.9 \mathrm{~mm} /$ year, respectively. While the relative mean sea level change at Bodrum-II is found to be in acceptable agreement with global sea level rise estimates, those obtained from Antalya-II, Mentes, and Erdek are much higher than global estimates.

\section{Data and Method}

A rise in sea level would cause erosion and inundation and also move the zones at risk of flooding upward and landward (Nicholls et al. 1999). According to Behnen (2000), areas below $10 \mathrm{~m}$ are most vulnerable to SLR. Lower slopes are at greater risk of flood due to SLR compared with steeper slopes (Nicholls et al. 1999).

Extensive assessments of SLR require exact maps of the entire coastal zone, but map scales and accuracy change across nations. Given that the typical error in SRTM altitudes is on the order of $3 \mathrm{~m}$ in most coastal areas (Rodriguez et al. 2005), there may be better local data which are not publicly available, such as LIDAR, for our

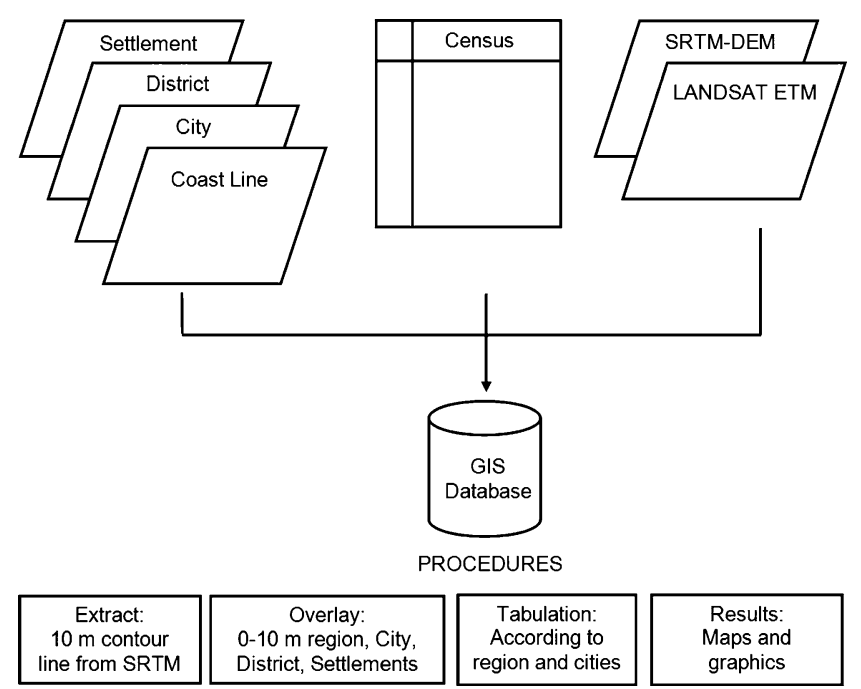

Fig. 2 GIS data model and procedures

region of interest. The SRTM dataset at $90-\mathrm{m}$ resolution is the best publicly available topographic dataset for nearglobal use.

The SRTM digital elevation data, originally produced by the National Aeronautics and Space Administration (NASA), were a major breakthrough in digital mapping of the world and provide a major advance in the accessibility of high-quality elevation data for large portions of the tropics and other areas of the developing world. The SRTM 90-m digital elevation models (DEMs) have a resolution of $90 \mathrm{~m}$ at the equator and are provided as a $5^{\circ} \times 5^{\circ}$ mosaic for easy interpretation.

Landsat data were provided through NASA's Earth Science Enterprise Scientific Data Purchase Program Produced, under NASA contract, by Earth Satellite Corporation. The dataset is entitled GeoCover Orthorectified Landsat Thematic Mapper Mosaics and was published by NASA's Stennis Space Center. These data are available without copyright restriction and can be obtained from the Land Processes Distributed Active Archive Center at EROS Data Center.

Vector, raster, and tabular data were used for risk assessment of SLR (Table 1). Census data for city and

Table 1 Data source and type

\begin{tabular}{llll}
\hline Data name & Data type & Scale/Resolution & Producer \\
\hline SRTM-DEM & Raster & $-/ 90 \mathrm{~m}$ & NASA 2007 \\
Settlements & Vector-Point & $1: 500,000 /-$ & \\
District boundary & Vector-Region & $1: 500,000 /-$ & \\
City boundary & Vector-Region & $1: 500.000 /-$ & \\
Coastline & Vector-Line & $1: 500,000 /$ Mixture of $14.25 \mathrm{~m}$ & Digitized from satellite data \\
Satellite data & Raster & $-/$ Mixture of $14.25 \mathrm{~m}$ & NASA, LADSAT TM-ETM+, 1990-2000 \\
Census & Attribute-Table & $-/-$ & NSI 2007 and YerelNET 2007 \\
\hline
\end{tabular}


Table 2 General results of national assessment

\begin{tabular}{lcr}
\hline Coastal district level & Average & Sum \\
\hline City & & 28 \\
District (ilce) & & 191 \\
Settlements (village or town) & $130,909.4$ & 181 \\
Population (person) & 13.87 & $25,003,696$ \\
Population increment rate (\%) & 172.74 & \\
Population density (person/km $\left.{ }^{2}\right)$ & $184,012.65$ & $29,626,036$ \\
Income from national budget (TL) & 0.0776679 & 12.5045 \\
Income tax rate (\%) & 0.1713780 & 27.5918 \\
Agricultural production rate (\%) & & $7,319.561$ \\
Area within 0-10 m $\left(\mathrm{km}^{2}\right)$ & & 181 \\
Settlements within $0-10 \mathrm{~m}$ & & $1,679,036$ \\
Population within $0-10 \mathrm{~m}$ & & \\
\hline
\end{tabular}

district populations were obtained from the National Statistical Institute 2007 census. Village and other small settlement population data were obtained from a local government web portal of Turkey which was developed by the Local Government Research and Training Centre of The Public Administration Institute for Turkey and the Middle East and financially supported by the Turkish State Planning Organization (YerelNET 2007). Population increment rate, population density, income from national budget for each person, income tax rate, and agricultural production rate were obtained from Dincer and Ozaslan (2004).

Point and region vector data were used to create a GIS database. The point vector data were settlements and cities, and the region vector data were districts and boundaries. Vector data were extracted from 1:500,000 scale cartographic maps by manual digitizing methods. Global Mapper software was used to process raster data, such as scanned maps and SRTM data. MapInfo software was used to establish vector and attribute database in GIS.
The GIS model was used in this assessment by combining spatial coastal data with common sea level rise projections. GIS data model and procedures are provided in Fig. 2.

A first-order estimate of potential losses of land to SLR was arrived at by integrating digital elevation data with SLR scenarios using a GIS. Average tidal range values were estimated for all coastal administrative units. Then, based on these values and using the elevation dataset, land area loss as a function of SLR was calculated for each administrative unit. In this step, low-lying inland areas and water bodies were masked out. First-order estimates of population exposure to SLR were calculated by combining the above data. These datasets were then used to calculate resident coastal population counts for the areas lost based on 2007 census data. Finally, each coastal city was examined according to eight parameters (district, population, settlements (within 0-10 m), population (within 0-10 m), area (within 0-10 m),
Fig. 3 Distribution of land area within $0-10 \mathrm{~m}$
Distribution of land area within $0-10 \mathrm{~m}$

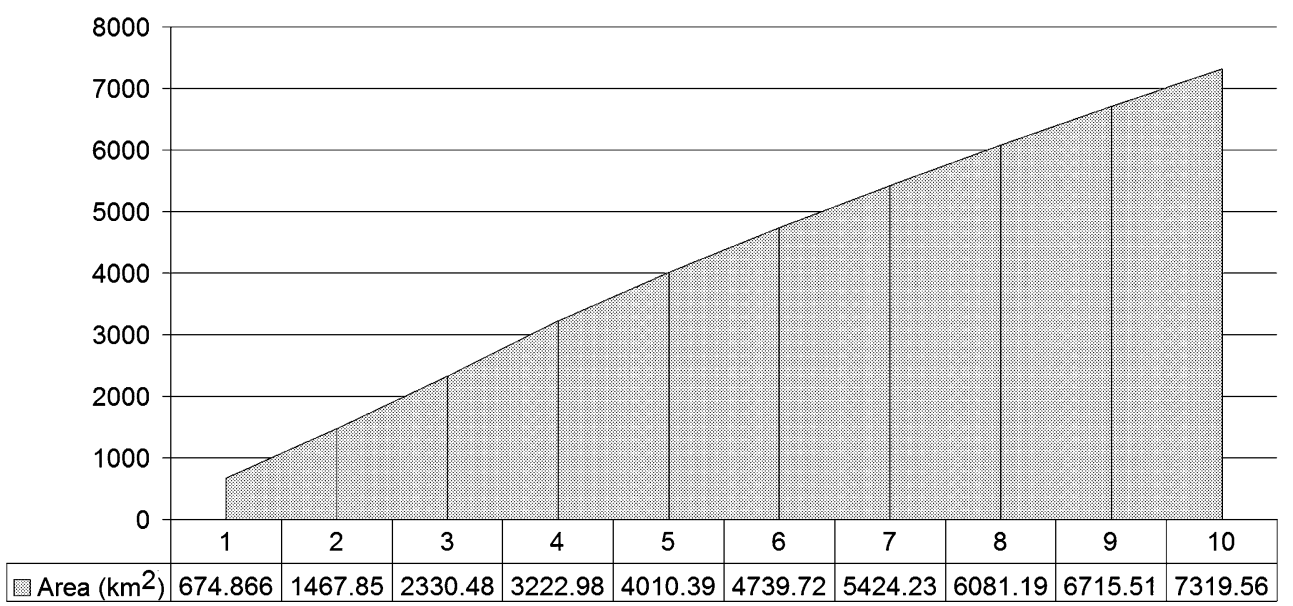




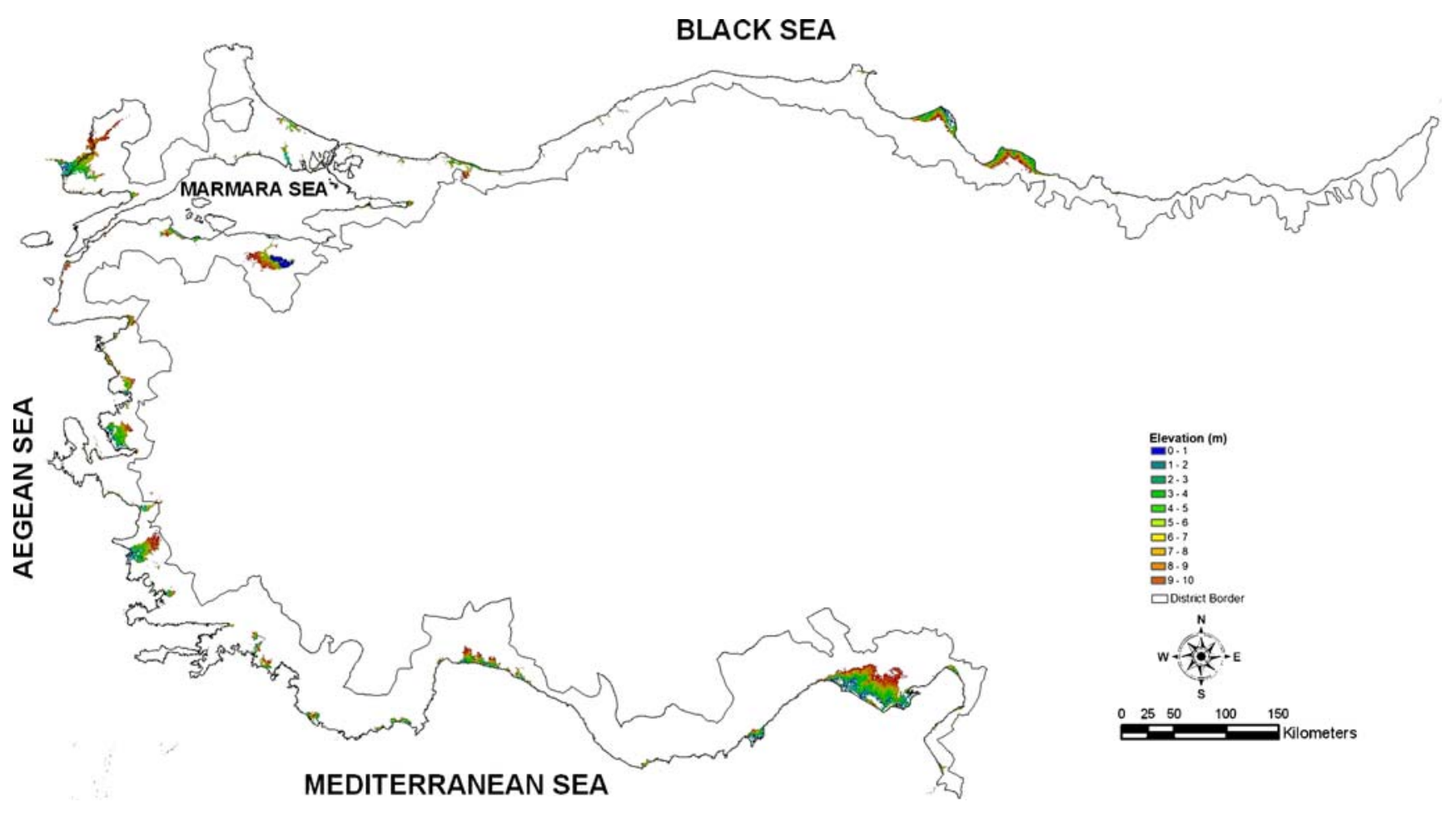

Fig. 4 Coastal areas below 10-m elevation above the present mean sea level

income from national budget (TL), income tax rate (\%), and agricultural production rate $(\%)$ ). The following formula (1) was used to predict a vulnerability index for each coastal city and district:

$V=\sum_{i=1}^{n} K_{i} / n$

where $V$ is vulnerability, $n$ is parameter, and $K$ is order among each city. For instance, the city of Izmir is second in district number, second in population, third in settlements within $0-10 \mathrm{~m}$, fourth in population within $0-10 \mathrm{~m}$, third for area within $0-10 \mathrm{~m}$, fourth for income from national budget, fifth for income tax rate, and fifth for agricultural production rate among 28 coastal cities. In this instance, vulnerability for the cities of Izmir and Artvin is as follows:

$V_{\mathrm{i}}=(2+2+3+4+3+4+5+5) / 8=3.5$

$$
\begin{aligned}
V_{\mathrm{a}} & =(27+26+27+27+28+25+24+28) / 8 \\
& =26.5 .
\end{aligned}
$$

Consequently, $V$ is between 1 and 28. The smaller the $V$ value, the greater the vulnerability.

Table 3 Regional vulnerability

\begin{tabular}{lcccccccccc}
\hline Region & City & Districts & Populations & $\begin{array}{l}\text { Settlements } \\
\text { (within } 0- \\
10 \mathrm{~m})\end{array}$ & $\begin{array}{l}\text { Populations } \\
\text { (within } 0- \\
10 \mathrm{~m})\end{array}$ & $\begin{array}{l}\text { Areas } \\
\text { (within } \\
0-10 \mathrm{~m})\end{array}$ & $\begin{array}{l}\text { Income } \\
\text { from } \\
\text { national } \\
\text { budget (TL) }\end{array}$ & $\begin{array}{l}\text { Income } \\
\text { tax rate } \\
(\%)\end{array}$ & $\begin{array}{l}\text { Agricultural } \\
\text { production } \\
\text { rates }(\%)\end{array}$ & $\begin{array}{l}\text { Risk } \\
\text { value }\end{array}$ \\
\hline Mediterranean & 4 & 27 & $5,634,047$ & 60 & 427,815 & $2,669.9$ & $3,384,824$ & 2.69284 & 10.83841 & 8.156 \\
Aegean & 3 & 31 & $3,634,161$ & 38 & 208,226 & $1,833.3$ & $4,588,819$ & 1.55674 & 3.93627 & 8.375 \\
Marmara & 9 & 69 & $12,049,152$ & 32 & 841,789 & $1,698.5$ & $15,152,501$ & 5.68526 & 5.91736 & 9.542 \\
Black Sea & 12 & 63 & $3,686,336$ & 51 & 201,206 & $1,140.9$ & $6,499,892$ & 2.56969 & 6.8998 & 18.677 \\
\hline
\end{tabular}




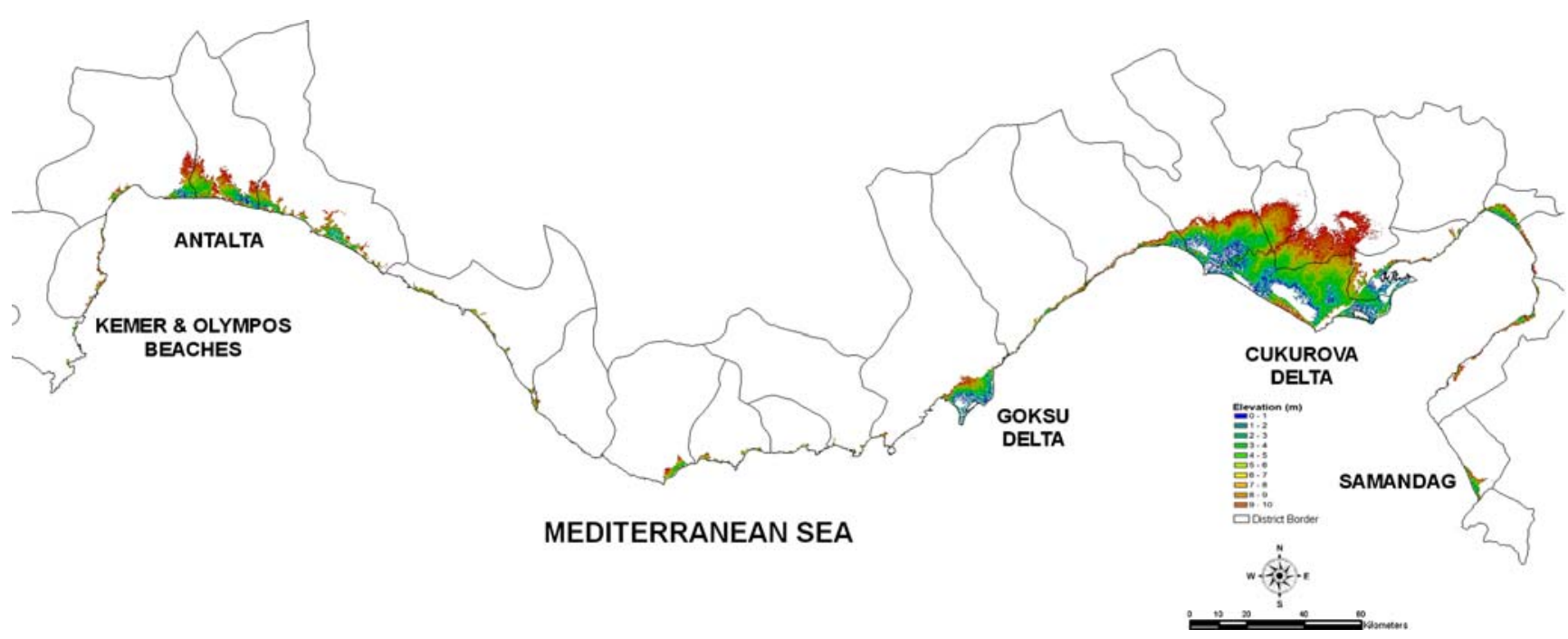

Fig. 5 Potential land losses in the Mediterranean Region

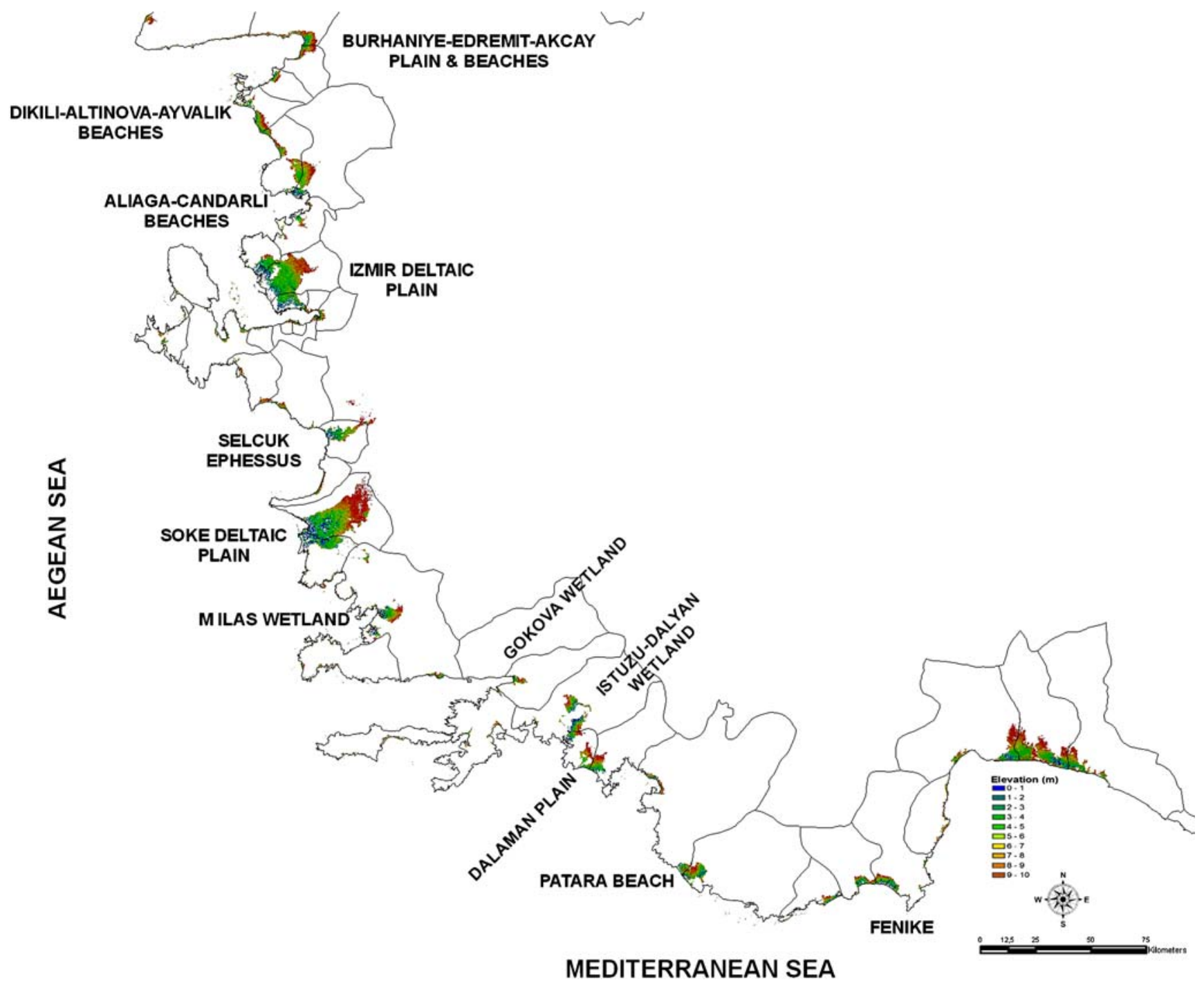

Fig. 6 Potential land loss in the Aegean Region 


\section{Results and Discussion}

Turkish coastal zone elevation to SLR was illustrated using digital elevation and GIS models. Table 2 shows the general results of the national assessment. Approximately $7,319 \mathrm{~km}^{2}$ of land area lies below the $10-\mathrm{m}$ contour line in Turkey. Hence, it is highly vulnerable to SLR. Twentyeight coastal cities, 191 districts, and 181 villages or towns are located in the area below the $10-\mathrm{m}$ contour line. Thus, $\sim 10 \%$ of national land lies within the 0 - to $10-\mathrm{m}$ contour line. These areas have significant value in terms of agricultural production, population, taxes, and income. For example, over 25 million people live in these areas and nearly $27.5 \%$ of national agricultural production and $12.5 \%$ income tax are obtained from these coastal areas.

In order to estimate the extent of the regions vulnerable to SLR, various data on national land distribution with respect to elevation above sea level were compiled. Figure 3 shows potential coastal land loss from inundation, excluding protection and erosion, in the event of an increase of $10 \mathrm{~m}$ in global mean sea level.

Figure 4 illustrates the spatial distribution of land area below the $10-\mathrm{m}$ line. Land distribution rises as a linear function of elevation above the mean high water line. There are large areas within 10-m elevation of the current mean high water line, partly reflecting the extensive area of natural and intertidal habitats along Turkish shores.
Turkey has a long coastal zone, the characteristics of which change across regions. Hence, potential land losses and other risks due to the SLR were examined according to region.

Regional vulnerability was calculated using nine parameters [number of cities, district, population, settlements (within $0-10 \mathrm{~m}$ ), population (within $0-10 \mathrm{~m}$ ), area (within $0-10 \mathrm{~m}$ ), income from national budget (TL), income tax rate (\%), and agricultural production rate (\%)] (Table 3). As shown in Table 3, although the Marmara Region is the most vulnerable area in terms of population at risk, the Mediterranean Region is the area most vulnerable to land loss (Fig. 5).

In the Mediterranean Region, the greatest potential land losses are along the East Mediterranean coast, including the Samandag sand dune nesting area for sea turtles, the Cukurova Delta Plain, the Goksu Delta, and the Antalya tourism center. In Antalya, many beaches which are important for tourism and their infrastructure, for example, the Belek, Kemer, Phaselis, Oliympos, Finike, and Patara beaches and the Beymelek Lagoon, are also situated on lowland. It is predicted that SLR will have a negative impact on these area, and they are inundated yearly, especially during the rainy season (Fig. 6).

The Aegean coast is vulnerable to significant land loss. It is estimated that approximately $1,833 \mathrm{~km}^{2}$ lies below the $10-\mathrm{m}$ contour line in Aegean coastal zones, defined as extended agricultural lowland and wetlands. Fethiye Oludeniz, Dalaman plain, Istuzu beach, Dalyan, Gokova and

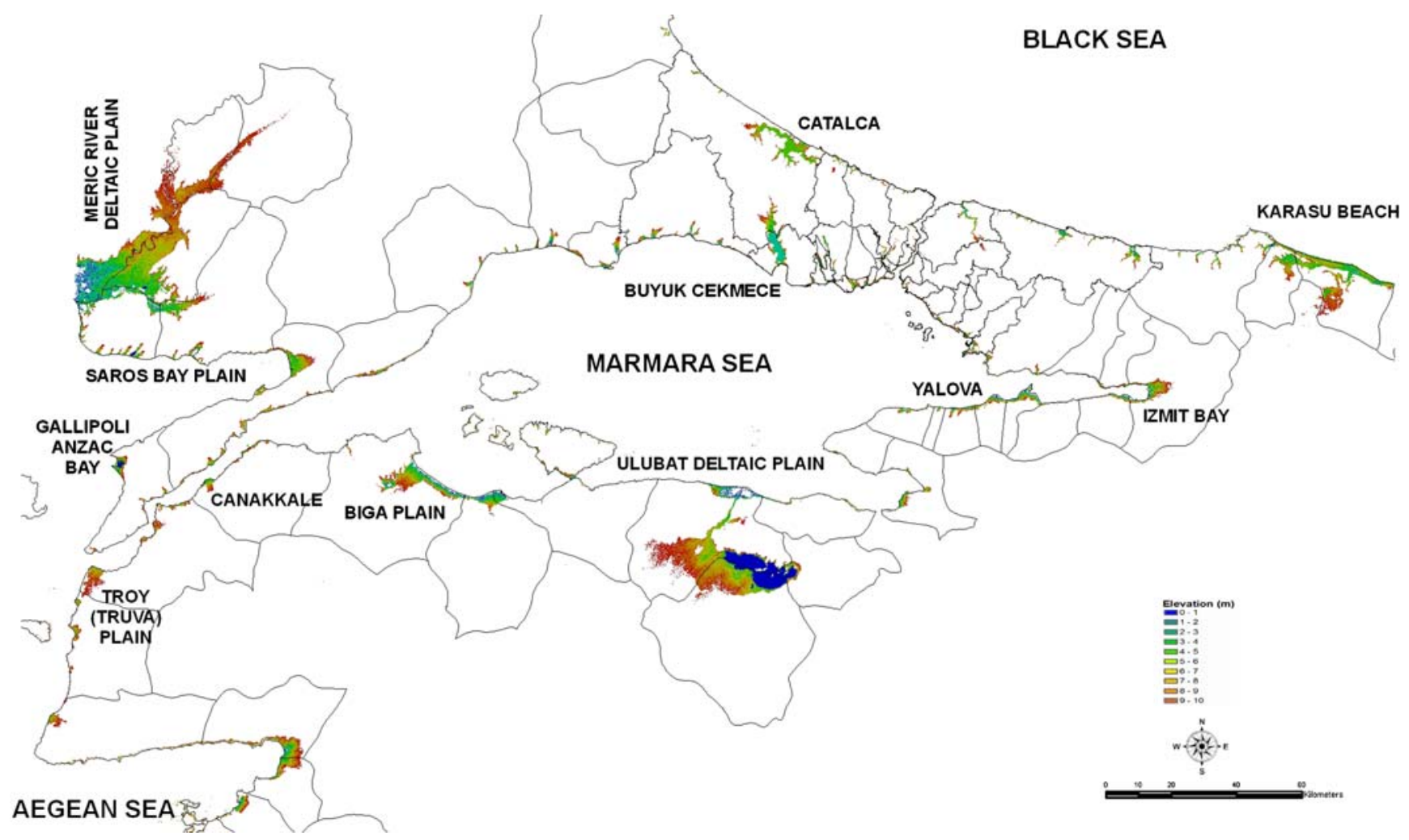

Fig. 7 Potential land losses in the Marmara Region 


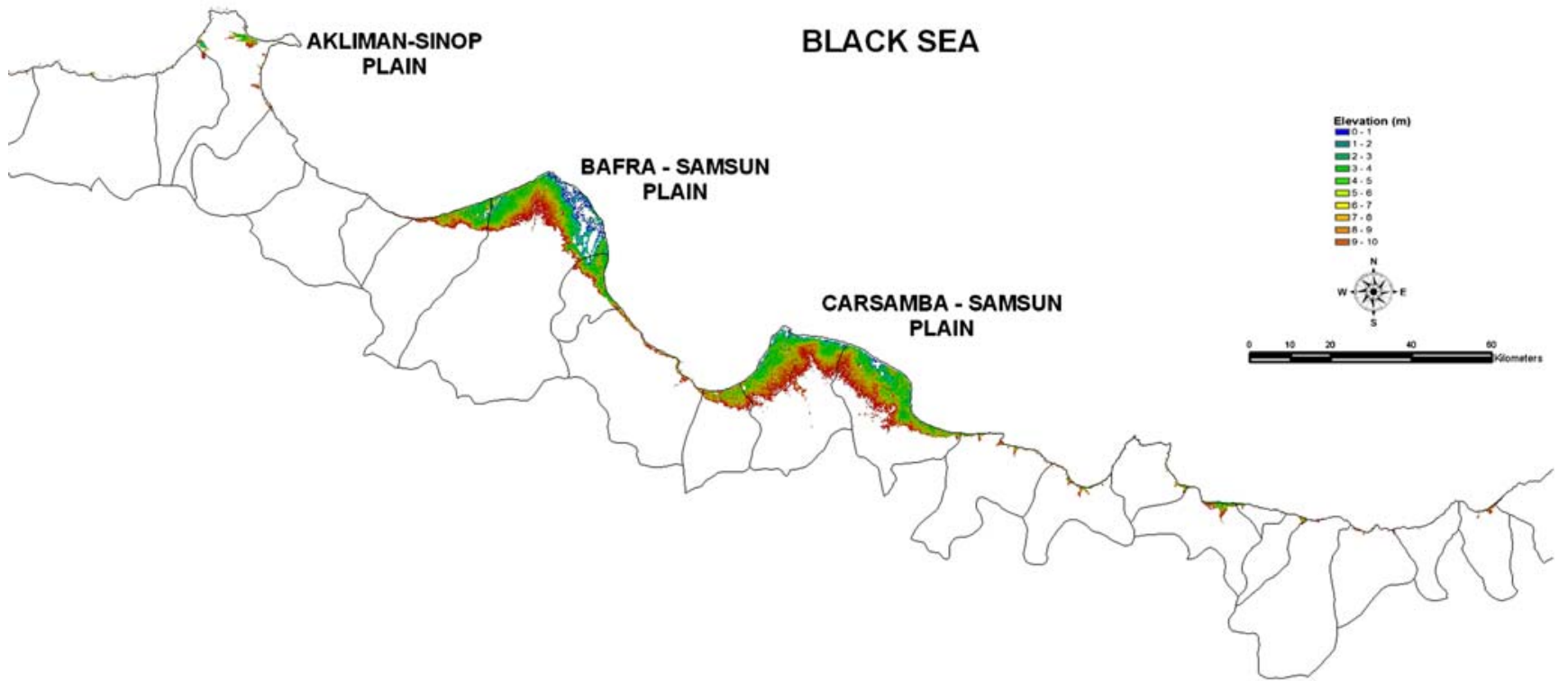

Fig. 8 Potential land losses in the Black Sea Region

Milas wetlands, Soke plain and wetland, the ancient city of Selcuk Ephessus, Izmir Gediz River wetland and deltaic plain, and Candarl, Dikili, Altinova, Ayvalik, Burhaniye, Edremit, and Akcay beaches are vulnerable lowlands in the Aegean Region (Fig. 7).

The Marmara Region has very sensitive ecosystems, especially the Meric (Evros) delta for seasonal bird migration. Wetlands, such as the Gala Lake, are very sensitive to saltwater intrusion from the Aegean Sea if the stream level is not high enough in the Meric River. It enters into Meric upstream of the transboundary delta. There are a million people, many industries, and extensive agriculture. The ancient city of Truva, the Canakkale, Gelibolu, Saros, Biga and Ulubat deltaic plains, and Yalova and Izmit bays are the most vulnerable lowlands in the Marmara Region (Fig. 8).

The delta rivers in Carşamba and Bafra constitute most of the natural lakes in the Black Sea region. The Bafra lakes

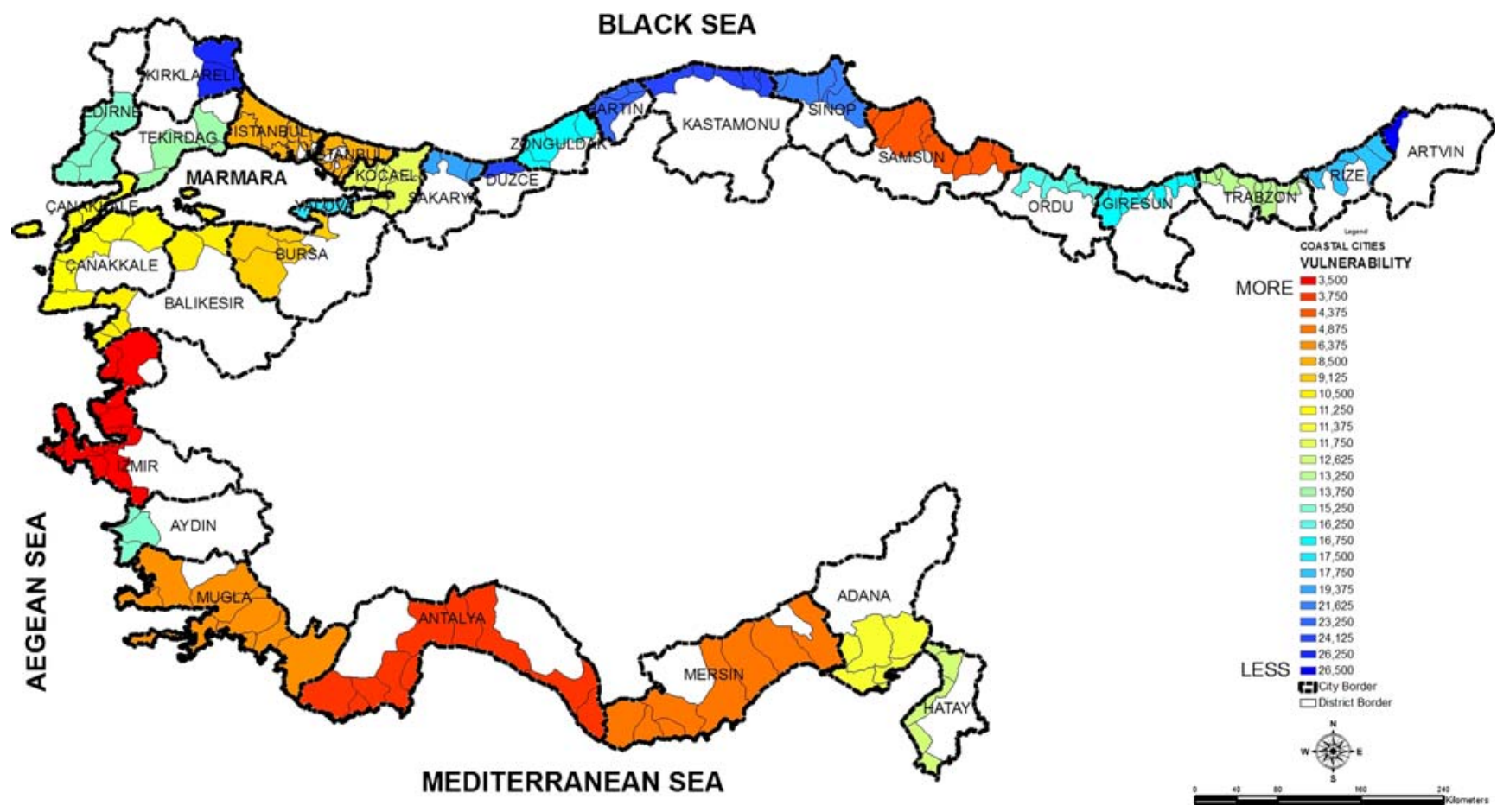

Fig. 9 Vulnerability map of coastal cities 
Table 4 Characteristics of coastal cities

\begin{tabular}{|c|c|c|c|c|c|c|c|c|c|}
\hline City name & District & Population & $\begin{array}{l}\text { Settlements } \\
\text { within } 0- \\
10 \mathrm{~m}\end{array}$ & $\begin{array}{l}\text { Population } \\
\text { within } 0- \\
10 \mathrm{~m}\end{array}$ & $\begin{array}{l}\text { Area } \\
\text { within } \\
0-10 \mathrm{~m}\end{array}$ & $\begin{array}{l}\text { Population } \\
\text { rate }\end{array}$ & $\begin{array}{l}\text { Income } \\
\text { from } \\
\text { national } \\
\text { budget } \\
\text { (TL) }\end{array}$ & $\begin{array}{l}\text { Income } \\
\text { tax rate } \\
(\%)\end{array}$ & $\begin{array}{l}\text { Agricultural } \\
\text { production } \\
\text { rate }(\%)\end{array}$ \\
\hline
\end{tabular}

\begin{tabular}{|c|c|c|c|c|c|c|c|c|c|c|}
\hline Adana & 4 & $1,729,356$ & 15 & 27,140 & 1385.12 & 1.57 & 169,635 & 0.09504 & 1.37683 & 11.375 \\
\hline Antalya & 10 & $1,753,105$ & 22 & 145,776 & 537.47 & 8.32 & $1,547,966$ & 1.28767 & 4.2318 & 3.75 \\
\hline Artvin & 2 & 51,345 & 0 & 0 & 1.86 & 0 & 242,786 & 0.03312 & 0.01982 & 26.5 \\
\hline Aydin & 3 & 231,748 & 6 & 17,013 & 506.90 & 7.34 & 524,474 & 0.19716 & 0.42745 & 15.25 \\
\hline Balikesir & 8 & 531,087 & 3 & 11,235 & 182.23 & 2.12 & $1,516,094$ & 0.539 & 0.82754 & 10.5 \\
\hline Bartin & 3 & 157,843 & 0 & 0 & 9.91 & 0 & 260,018 & 0.08647 & 0.1012 & 23.25 \\
\hline Bursa & 5 & 592,913 & 7 & 47,211 & 459.82 & 7.96 & $4,309,354$ & 0.21257 & 1.26259 & 9.125 \\
\hline Canakkale & 9 & 354,964 & 3 & 10,775 & 224.63 & 3.04 & 913,441 & 0.22896 & 1.10447 & 11.25 \\
\hline Duzce & 1 & 36,944 & 1 & 853 & 6.10 & 2.31 & 45,583 & 0.0154 & 0.10017 & 24.125 \\
\hline Edirne & 5 & 206,332 & 4 & 5,924 & 437.81 & 2.87 & 446,330 & 0.10476 & 1.0223 & 15.25 \\
\hline Giresun & 8 & 310,848 & 2 & 8,300 & 14.58 & 2.67 & 546,348 & 0.17615 & 0.81417 & 16.75 \\
\hline Hatay & 5 & 633,848 & 2 & 166,543 & 76.97 & 26.27 & 889,769 & 0.42584 & 1.30221 & 12.625 \\
\hline Istanbul & 23 & $8,271,951$ & 7 & 553,778 & 244.30 & 6.69 & 773,281 & 0.673 & 0.36121 & 8.5 \\
\hline Izmir & 18 & $2,694,607$ & 21 & 116,147 & 754.95 & 4.31 & $2,130,935$ & 0.67491 & 1.40778 & 3.5 \\
\hline Kastamonu & 6 & 72,728 & 0 & 0 & 3.42 & 0 & 300,660 & 0.02249 & 0.08896 & 24.125 \\
\hline Kirklareli & 2 & 39,476 & 0 & 0 & 13.25 & 0 & 243,669 & 0.02171 & 0.08169 & 26.25 \\
\hline Kocaeli & 7 & $1,437,926$ & 1 & 1,520 & 60.10 & 0.11 & $3,223,215$ & 3.2323 & 0.39576 & 11.75 \\
\hline Mersin & 8 & $1,517,738$ & 21 & 88,356 & 670.35 & 5.82 & 777,454 & 0.88429 & 3.92757 & 4.875 \\
\hline Mugla & 10 & 707,806 & 11 & 75,066 & 417.49 & 10.61 & $1,933,410$ & 0.68467 & 2.10104 & 6.375 \\
\hline Ordu & 5 & 418,686 & 2 & 3,960 & 23.70 & 0.95 & 408,327 & 0.22985 & 0.76359 & 16.25 \\
\hline Rize & 7 & 276,525 & 0 & 0 & 3.68 & 0 & 799,008 & 0.20345 & 0.78358 & 17.75 \\
\hline Sakarya & 3 & 99,483 & 5 & 21,334 & 150.30 & 21.44 & 70,967 & 0.02509 & 0.42833 & 19.375 \\
\hline Samsun & 8 & 965,570 & 37 & 37,325 & 887.54 & 3.87 & $1,653,201$ & 0.65335 & 2.61182 & 4.375 \\
\hline Sinop & 6 & 128,411 & 0 & 0 & 16.34 & 0 & 390,474 & 0.06491 & 0.15164 & 21.625 \\
\hline Tekirdag & 4 & 432,745 & 4 & 27,234 & 36.68 & 6.29 & $3,151,198$ & 0.49162 & 0.69358 & 13.75 \\
\hline Trabzon & 10 & 638,438 & 4 & 129,434 & 7.245 & 20.27 & 621,544 & 0.44712 & 0.77265 & 13.25 \\
\hline Yalova & 6 & 181,758 & 3 & 184,112 & 39.67 & 101.30 & 575,919 & 0.18134 & 0.16822 & 17.5 \\
\hline Zonguldak & 4 & 529,515 & 0 & 0 & 16.20 & 0 & $1,160,976$ & 0.61229 & 0.26387 & 16.75 \\
\hline
\end{tabular}

resulted from filling the depressions on each side of Kizilirmak River which passes through the Bafra Plain. Most of these lakes are rich in terms of aquaculture and have economic significance. This region also has national importance in terms of the variety of birds it supports. The Kizilirmak Delta is the largest and most significant wetland area of Turkey which protects the coastline on the Black Sea coast. The ecological system of the delta is extremely rich in terms of biological variety.

\section{Conclusion}

Figure 9 shows a map of the risk value for the Turkish coast. The calculated risk values range from 3.5 to 26.5 . A total of $7,319 \mathrm{~km}^{2}$ lying below the 10 -m contour line was ranked in the study area. Each coastal city was examined according to eight parameters (Table 4). These parameters are districts, district populations, settlements, populations, areas, income from national budget (TL), income tax rate $(\%)$, and agricultural production rates (\%) within the 0 - to 10-m contour line.

Using Eq. 1, vulnerability was calculated for each coastal city. After encoding the vulnerability estimates into the GIS database, vulnerability was mapped out (Fig. 9).

As shown in Fig. 9, the mapped risk values indicate numerous areas of high vulnerability, particularly in the Cukurove Delta, Antalya, Izmir, Istanbul, and Samsun where the coast is most highly populated, with low-lying beach areas. Although the Marmara Region is the most 
vulnerable area in terms of population at risk, the Mediterranean Region is the most vulnerable in terms of potential land loss.

The lowest risk, least vulnerable areas generally occur at rocky foreland along less densely populated cliffed coasts where the slope is steep and mountain ranges run parallel to the coastline. Examples of such areas are the coasts of Duzce, Bartin, Kastamonu, Sinop, and Artvin in the Black Sea region.

Global SLR for the last century has been estimated at 10-20 cm for the Mediterranean and Black Sea regions. The SLR was $\sim 12 \mathrm{~cm}$ in the last century (MoEF 2007). Although coastal settlements below the 10-m contour line account for $\sim 10 \%$ of total land coverage in Turkey, more than 25 million people reside in coastal areas.

Erosion, flooding, and inundation along Turkish coastlines are problems of national significance, particularly in the Aegean and Mediterranean regions and two important agricultural deltaic plains in the Black Sea region. Touristic coastal cities are particularly threatened as many cultural sites, including ancient cities in the Mediterranean and Aegean regions, would be destroyed by SLR.

Deltaic coastlines are expected to undergo change due SLR, which will increase flooding across the delta plains and disrupt agricultural activity. There are several options for managed retreat and accommodation strategies in Turkey. For instance, land use planning in coastal zones, such as using building setbacks or allocating low-lying vulnerable lands to lower value uses (i.e., parks rather than tourism), would help reduce their overall vulnerability to SLR and other coastal hazards. Such measures, however, have not been seriously considered in Turkey.

Turkey, being a coastal country, recognizes the increasing number of problems in coastal zones, and many safety measures are being taken by several government institutions and agencies (MoEF 2007). For example, most of the areas in the Aegean and Mediterranean coasts were declared protected zones by the Turkish government. In the short term, to address the negative impact of SLR, The Turkish Ministry of Environment should declare new areas as protected zones and develop special national-level environmental programs.

Open Access This article is distributed under the terms of the Creative Commons Attribution Noncommercial License which permits any noncommercial use, distribution, and reproduction in any medium, provided the original author(s) and source are credited.

\section{References}

Adam, K.S. 1995. Vulnerability assessment and coastal management program in the Benin coastal zone. In Proceedings of WCC93.
CZM Management Publication No. 4, ed. P. Beukenkamp, 489501. The Hague: National Institute for Coastal and Marine Management.

Baarse, G., E.B. Peerbolte, and I. Bijlsma. 1994. Assessment of the vulnerability of the Netherlands to sea-level rise. In Global climate change and the rising challenge of the Sea. Proceedings of the 3rd IPCC CZMS Workshop, Margarita Island, March 1992, ed. J. O'Callahan, 211-236. Silver Spring: NOAA.

Behnen, T. 2000. Der beschleunigte Meeresspiegelanstieg und seine sozioökonomischen Folgen: Eine Untersuchung der Ursachen, methodischen Ansätze und Konsequenzen unter besonderer Berücksichtigung Deutschlands. Hannover, Germany: Hannoversche Geographische Arbeiten 54, 224 pp.

Bijlsma, L., C.N. Ehler, R.J.T. Klein, S.M. Julshrestha, R.F. McLean, N. Mimura, R.J. Nicholls, L.A. Nurse, N.H. Perez, E.Z. Stakhiv, R.K. Turner, and R.A. Warrick. 1996. Coastal zones and small islands. In Impacts, adaptations, and mitigation of climate change: Scientifictechnical analyses, ed. R.T. Watson, M.C. Zinyowera, and R.H. Moss, 289-324. Cambridge: Cambridge University Press.

Church, J.A., J.M. Gregory, P. Huybrechts, M. Kuhn, K. Lambeck, M. T. Nhuan, D. Qin, and P.L. Woodworth. 2001. Changes in sealevel. In Climate change 2001: Impacts adaptation and vulnarability. IPCC Working Group II, ed. J.J. McCarthy, O. Canziani, N.A. Leary, D.J. Dokken, and K.S. White, 639-693. Cambridge: Cambridge University Press.

Church, J.A., et al. 2008. Understanding global sea-levels, past, present and future. Sustainability Science 3(1): 9-22.

Demirkesen, A.C., F. Evrendilek, S. Berberoglu, and S. Kilic. 2007a. Coastal flood risk analysis using Landsat-7 ETM+ imagery and SRTM DEM: A case study of Izmir, Turkey. Environmental Monitoring and Assessment Journal 131(1-3): 293-300.

Demirkesen, A.C., F. Evrendilek, and S. Berberoglu. 2007b. Quantifying coastal inundation vulnerability of Turkey to sea-level rise. Environmental Monitoring and Assessment Journal 138: 101106.

Deniz, H. 2002. Aquaculture development and lagoons in the mediterranean and the Black Sea Coastlines of Turkey. Extended abstracts and short communications at the International Conference on Aquaculture Europe 2002-Sea farming today and tomorrow, Trieste, Italy, October 16-19, 2002. EAS Special Publication No.32, pp. 204-205.

Dennis, K., I. Niang-Diop, and R.J. Nicholls. 1995. Sea-level rise and Senegal: Potential impacts and consequences. Journal of Coastal Research 14: 242-261.

Dincer, B., and M. Ozaslan. 2004. Grading to districts by according to socio-economical development. Ankara: Turkish State Planning Organization. $256 \mathrm{pp}$.

French, G.T., L.F. Awosika, and C.E. Ibe. 1995. Sea-level rise in Nigeria: Potential impacts and consequences. Journal of Coastal Research 14: 224-242.

Gunay, T. 1987. The management of coastal areas. Development perspectives, Turkey. United Nations Economic Commission for Europe, 14th Session, Portugal, November 1987.

Han, M., J. Hou, and I. Wu. 1995. Potential impacts of sea-level rise on China's coastal environment and cities: A national assessment. Journal of Coastal Research 14: 79-95.

Hulme, M., G. Jenkins, X. Lu, J.R. Turnpenny, T.D. Mitchell, R.G. Jones, J. Lowe, J.M. Murphy, D. Hassell, P. Boorman, R. McDonald, and S. Hill. 2002. Climate change scenarios for the United Kingdom: The UKCIPO2 scientific report. Norwich: Tyndall Centre for Climate Change Research, University of East Anglia. $120 \mathrm{pp}$.

IPCC. 2001. In Climate change 2001: Impacts, adaptation and vulnerability, ed. J.J. McCarthy, O.F. Canziani, N.A. Leary, D.J. 
Dokken, and K.S. White. Cambridge: Cambridge University Press.

IPCC (2007) In: Solomon S, Qin D, Manning M, Chen Z, Marquis MC, Averyt K, Tignor M, Miller HL (eds) Climate change 2007: The physical science basis. Contribution of Working Group 1 to the Fourth Assessment Report of the Intergovernmental Panel on Climate Change. Intergovernmental Panel on Climate Change, Cambridge University Press, Cambridge

Meehl, G.A., T. F. Stocker, W. Collins, P. Friedlingstein, A. Gaye, J. Gregory, A. Kitoh, R. Knutti, J. Murphy, A. Noda, S. Raper, I. Watterson, A. Weaver and Z. Zhao. 2007. Global climate projections. Climate Change 2007: The physical science basis. Contribution of Working Group I to the Fourth Assessment Report of the Intergovernmental Panel on Climate Change. Solomon, S., D. Qin, M. Manning, Z. Chen, M. Marquis, K.B. Averyt, M. Tignor and H.L. Miller, eds. Cambridge University Press, Cambridge and New York, pp. 747-846.

Ministry of Environment. 2001. The national strategy and action plan for biodiversity in Turkey.

Ministry of Environment. 2002. National report on sustainable development 2002. Ministry of Republic of Turkey.

MoEF. 2007. First National Communication of Turkey on Climate Change. G. Apak, and B. Ubay, eds. The Ministry of Environment and Forestry (MoEF), General Directorate of Environmental Management, $276 \mathrm{pp}$.

NASA. 2007. The Shuttle Radar Topography Mission (SRTM). http:// www2.jpl.nasa.gov/srtm/.

National Statistical Institute. 2007. General results of Census 2007. http://www.turkstat.gov.tr.

Ng, W.S., and R. Mendelshon. 2005. The impact of sea-level rise on Singapore. Environment and Development Economics 10(2): 201-215.

Nicholls, R.J. 2003. Case study on sea-level rise impacts. Prepared for OECD Workshop on the Benefits of Climate Policy: Improving Information for Policy Makers: December 12-13, 2002. Working Party on Global and Structural Policies, Organization for Economic Cooperation and Development, Paris.

Nicholls, R.J., and N. Mimura. 1998. Regional issues raised by sealevel rise and their policy implications. Climate Research 11: 518.

Nicholls, R.J., and C. Small. 2002. Improved estimates of coastal population exposure to hazards released. Eos 83: 303-305.
Nicholls, R.J., and R.S.J. Tol. 2006. Impacts and responses to sealevel rise: A global analysis of the SRES scenarios over the twenty-first century. Philosophical Transactions of the Royal Society, A 364(1841): 1073-1095.

Nicholls, R.J., F.M.J. Hoozemans, and M. Marchand. 1999. Increasing flood risk and wetland losses due to global sea-level rise: Regional and global analysis. Global Environmental Change 9: 69-87.

PAP/RAC. 2005. Coastal area management in Turkey. Priority Actions Programme Regional Activity Centre, Split, 78 pp.

Rodriguez, E., C.S. Morris, J.E. Belz, E.C. Chapin, J.M. Martin, W. Daffer, and S. Hensley. 2005. An assessment of the SRTM topographic products. Technical Report JPL D-31639. Pasadena: Jet Propulsion Laboratory. 143 pp.

State Planning Organization (SPO). 2001. 8th Five-Year Development Plan, Watersheds, Watershed Usage and Management Special Task Committee Report. Ankara. http://ekutup.dpt.gov.tr/.

Tsimplis, M.N., D.K. Woolf, T.J. Osbourn, S. Wakelin, J. Wolf, R. Flather, P. Woodworth, A.G.P. Shaw, P. Challenor, and Z. Yan. 2004. Future changes of sea-level and wave heights at the northern European coasts. Geophysical Research Abstracts 6: 00332.

Warrick, R.A., C. Le Provost, M.F. Meier, J. Oerlemans, and P.L. Woodworth. 1996. Changes in sea-level. In Climate change 1995. The science of climate change, ed. J.T. Houghton, L.G. Meira Filho, B.A. Callander, N. Harris, A. Klattenberg, and K. Maskell, 359-405. Cambridge: Cambridge University Press.

Woodworth, P.L., J.M. Gregory, and R.J. Nicholls. 2005. Long term sea-level changes and their impacts. In The global coastal ocean: Multiscale interdisciplinary processes, ed. A.R. Robinson, and K. H. Brink, 715-753. Cambridge: Harvard University Press.

YerelNET. 2007. Web Portal of the Local Government Research and Training Centre of the Public Administration Institute for Turkey and the Middle East.

Yildiz, H., C. Demir, M.A. Gurdal, O.A. Akabali, E.O. Demirkol, M. Ayhan, and Y. Turkoglu. 2003. Analysis of sea-level and geodetic measurements of Antalya-II, Bodrum II, Erdek and Mentes tide gauges in the period of 1984-2002. General Command of Mapping, Map Periodical (Harita Dergisi), June, Special Issue 17.

Yim, W. 1995. Implications of sea-level rise for Victoria Harbour, Hong Kong. Journal of Coastal Research 14: 167-189.

Zeidler, R.B. 1997. Climate change variability and response strategies for the coastal zones of Poland. Climate Change 36: 151-173. 